\title{
Effect of Liquidity and Bank Size on the Profitability of Commercial Banks in Bangladesh
}

\author{
Shahnaz Parvin ${ }^{1}$, A. N. M. Minhajul Haque Chowdhury ${ }^{2 *}$, Ayesha Siddiqua ${ }^{3}$, Jannatul Ferdous ${ }^{4}$ \\ ${ }^{1}$ Associate Professor, Department of Finance and Banking, Hajee Mohammad Danesh Science and Technology University, Dinajpur-5200, \\ BANGLADESH \\ ${ }^{2}$ Credit Analyst, Department of Credit Risk Management, United Finance Limited, Dhaka, BANGLADESH \\ ${ }^{3} \mathrm{MBA}$, Department of Finance and Banking, Hajee Mohammad Danesh Science and Technology University, Dinajpur-5200, BANGLADESH \\ ${ }^{4}$ MBA, Department of Management, Hajee Mohammad Danesh Science and Technology University, Dinajpur-5200, BANGLADESH \\ *E-mail for correspondence: mhchowdhury2016@gmail.com
}

https://doi.org/10.18034/abr.v9i1.219

\begin{abstract}
Nowadays Modern economy cannot be thought without banks. The banks of Bangladesh have great contributions to the development of this country. This study concentrated on the commercial banks in Bangladesh to determine the effect of liquidity and bank size on the profitability of the banks during the year 2011-2015. Seven commercial banks were selected and descriptive as well as correlations analysis statistics were used to conduct the study. Data from the annual reports of the banks were analyzed. The results stated that loan to asset ratio and bank size had a positive relation with return on asset (ROA) which was the indicator of profitability. The results also showed that deposit to asset ratio had a negative impact on the ROA of the selected banks. Although there were relationships among liquidity, bank size and profitability but liquidity and bank size did not have a significant influence on the profitability of the banks.
\end{abstract}

JEL Classification Code: G 21

Key words: Commercial banks, liquidity, bank size, return on asset

\section{INTRODUCTION}

The banking sector is the most growing and influential industry in the economy of Bangladesh. In most cases the banking industry defines the development aspect of an economy. In the competitive banking world, banks are surviving through enhancing their performance and efficiency. Bank's profitability depends on some internal and external factors. These factors make an effort to fluctuate the net earnings of a bank. This study investigated the effect of two internal factors which are liquidity and bank size on the return on asset (ROA) of the selected commercial banks. Bank's ability to pay depositors within a short time is called liquidity and this is essential to operate the regular banking process without interruption. The size of total asset can be defined as bank size and this factor has much influence on banking profitability.

Objective of the Study

The main objective to conduct this study was to identify the influences and relationship of the determinants of profitability of banks such as liquidity and bank size on ROA of some selected Bangladeshi commercial banks.

\section{LITERATURE REVIEWS}

Liquidity helps a bank to reduce the chance of bank's failure to pay its depositors in regular transactions (Kumer and Sayani, 2015). Alshatti (2015) stated that it is essential to assure proper liquidity management for increasing the profitability of the banks.

Onuonga (2014) investigated six commercial banks in Kenya to determine the effect of internal factors those affect the profitability of the banks. He found that bank size, capital strength, ownership, operational expenses and diversification had a significant effect on the profitability which was measured by ROA.

Goddard et al. (2014) determined the profitability of banks through incorporation size, risk, diversification and ownership type. Their results stated that the relation between bank size and profitability was weak but the 
relationship between capital asset ratio and profitability of banks was positive.

Larty et al. (2013) investigated 9 (nine) listed banks from Ghana aiming at determining the relationship between profitability and liquidity for the year 2005-2010. They used ratio analysis, time series, correlations and regression analysis to find out the results. From their study, they found that the relationship between profitability and liquidity was positive but insignificant during that period.

Munir et al. (2012) conducted a study on the performance of the public sector banks in Pakistan. They selected some variables those were used to determine the banks' performance and the variables were total assets, advances, investments, deposits, profits after tax and ROA.

Ongore and Kusa (2013) studied on the determinants that affect the performance of the commercial banks in Kenya. They used return on equity, return on asset and net interest margin as the bank performance indicators whereas they capital adequacy, management efficiency, asset quality and liquidity as the internal factors and GDP growth rate and inflation rate as external factors for the study. Their study revealed that liquidity management and external variables did not have a significant effect but other than these all the variables had a significant effect on the performance of the 37 banks in Kenya for the period of 2001-2010.

Kedia (2016) used the non-performing asset, credit to deposit ratio, net interest income and operating expenses as independent variables and net profit as dependent variable to analyze the profitability of public sector banks in India.

Ayanda et al. (2013) investigated the Nigerian banking industry. They found that the size of the banks and cost efficiency did not have significant but credit risk and capital adequacy had significant on the profitability of the selected Banks in Nigeria.

Samad (2015) examined 42 Commercial Banks in Bangladesh to find out the determinants of the profitability of banks. He stated that bank size and macro economic variables were insignificant to profitability but bank-specific factors such as equity capital to total asset, loan to deposit ratio, loan loss provision to total asset and operating expenses had a significant effect on the profitability of the banks in Bangladesh.

Qin and Pastory (2012) conducted a study to measure the profitability of commercial banks in Tanzania. The results from the study indicated that liquidity and asset quality had a positive effect but level of nonperforming loans and capital adequacy had a negative effect on the profitability of the banks.

Dawood (2014) evaluated the profitability of commercial banks in Pakistan for the period 2009-2012. The internal factors of the study were management policies, capital ratios and risk management whereas inflation and government policies were the external factors. The profitability of the banks was determined by ROA which was the dependent variable of the study. The findings of the study suggested that cost deficiency, liquidity and capital adequacy had an influence on the profitability but bank size did not have any impact on the profitability of the banks in Pakistan.

Fisseha (2015) analyzed the profitability of commercial banks on the basis of bank size, capital adequacy, liquidity risk, credit risk, management efficiency, labor efficiency, inflation rate and real GDP rate.

Saad and Zhengge (2016) conducted a study to find out the effect of organizational factors such as liquidity, asset utilization, leverage, market share position and firm size on the ROA ROE of financial service firms.

\section{Research Methodology and Design}

Researchers collected annual reports of some commercial banks in Bangladesh and then randomly selected seven Commercial Banks to conduct the study which were -

- $\quad$ AB Bank Limited

- Bank Asia Limited

- Dhaka Bank Limited

- $\quad$ Eastern Bank Limited

- Mercantile Bank Limited

- Premier Bank Limited and

- Prime Bank Limited

The study investigated the banks for the year 2011-2015 and annual reports of the banks and journals were used as secondary sources of data. Loan to asset ratio (LA) and deposit to asset ratio (DA) were used as liquidity measurement and natural logarithm of total asset (log TA) were used as bank size where the return on asset (ROA) was the profitability indicating variable. The equations of the ratios are as follows:

i. Loan to Asset Ratio (LA) $=\frac{\text { Total Loans }}{\text { Total asset }}$

ii. Deposit to Asset Ratio $(\mathrm{DA})=\frac{\text { Total Deposit }}{\text { Total asset }}$

iii. Return on Asset (ROA)

$$
=\frac{\text { Earnings available to common shareholders }}{\text { Average Total Asset }}
$$

Researchers used the statistical tools such as mean, median, standard deviation (SD), minimum, and maximum and correlation analysis to analyze the result. Researchers used SPSS 16 software to determine the result.

\section{Hypothesis:}

$\mathrm{H}_{0}$ : Liquidity and bank size do not have a significant effect on profitability.

$\mathrm{H}_{1}$ : Liquidity and bank size have a significant effect on profitability. 


\section{RESULTS AND ANALYSIS}

Table 1 represents the loan to asset ratio, deposit to asset ratio, natural logarithm of total asset and returns on asset for the period from 2011-2015 successively. From table 2, we can see that the mean and standard deviation of the variables for each bank during the period and table 3 summarizes accumulate descriptive statistics (mean, median, standard deviation, minimum and maximum) of all the selected conventional banks.

Table 1: Ratio analysis of seven selected banks

\begin{tabular}{|c|c|c|c|c|}
\hline Year & LA & DA & $\begin{array}{c}\text { Bank Size } \\
\text { (log TA) }\end{array}$ & ROA \\
\hline \multicolumn{5}{|c|}{ AB Bank Limited } \\
\hline 2011 & 0.6636462 & 0.7501419 & 11.1886606 & 0.0096517 \\
\hline 2012 & 0.6475884 & 0.7971181 & 11.2443199 & 0.0088615 \\
\hline 2013 & 0.7014528 & 0.7704926 & 11.3216994 & 0.0057022 \\
\hline 2014 & 0.7444174 & 0.7983287 & 11.3947394 & 0.0065583 \\
\hline 2015 & 0.7540453 & 0.7446594 & 11.4577893 & 0.0054468 \\
\hline \multicolumn{5}{|c|}{ Bank Asia Limited } \\
\hline 2011 & 0.7054392 & 0.8052371 & 11.0724098 & 0.0182971 \\
\hline 2012 & 0.6613812 & 0.7800845 & 11.1499434 & 0.0065536 \\
\hline 2013 & 0.6539310 & 0.8098695 & 11.2176607 & 0.0086877 \\
\hline 2014 & 0.6512439 & 0.7641815 & 11.2650392 & 0.0115279 \\
\hline 2015 & 0.6159759 & 0.7539732 & 11.3534653 & 0.0124466 \\
\hline \multicolumn{5}{|c|}{ Dhaka Bank Limited } \\
\hline 2011 & 0.7233940 & 0.8118731 & 11.0213431 & 0.0229806 \\
\hline 2012 & 0.6794301 & 0.8039984 & 11.1258588 & 0.0066089 \\
\hline 2013 & 0.6902629 & 0.7976681 & 11.1625652 & 0.0142034 \\
\hline 2014 & 0.6484368 & 0.7814320 & 11.2035097 & 0.0137537 \\
\hline 2015 & 0.6668989 & 0.7820529 & 11.2485004 & 0.0089778 \\
\hline \multicolumn{5}{|c|}{ Eastern Bank Limited } \\
\hline 2011 & 0.6894772 & 0.6396793 & 11.0702755 & 0.0255121 \\
\hline 2012 & 0.6589448 & 0.6218180 & 11.1674486 & 0.0180850 \\
\hline 2013 & 0.6533170 & 0.7399744 & 11.1991058 & 0.0166122 \\
\hline 2014 & 0.6919507 & 0.6729820 & 11.2391507 & 0.0128941 \\
\hline 2015 & 0.7035874 & 0.6693445 & 11.2812408 & 0.0125235 \\
\hline \multicolumn{5}{|c|}{ Mercantile Bank Limited } \\
\hline 2011 & 0.6834497 & 0.8062571 & 11.0669044 & 0.0172302 \\
\hline 2012 & 0.6112897 & 0.7727179 & 11.1840267 & 0.0101687 \\
\hline 2013 & 0.6725071 & 0.8332908 & 11.1616745 & 0.0132800 \\
\hline 2014 & 0.6933210 & 0.7983437 & 11.2281455 & 0.0145249 \\
\hline 2015 & 0.6889934 & 0.8037205 & 11.2643010 & 0.0150848 \\
\hline \multicolumn{5}{|c|}{0.7951034} \\
\hline 2011 & 0.6640984 & 0.8097675 & 10.8747780 & 0.0071358 \\
\hline 2012 & 0.6387836 & 0.8204471 & 10.9124011 & 0.0077021 \\
\hline 2013 & 0.5860916 & 0.8282460 & 10.9538215 & 0.0091554 \\
\hline 2014 & 0.6279439 & 0.8309578 & 11.0475723 & 0.0095445 \\
\hline 2015 & 0.6947652 & 0.8283386 & 11.1187207 & 0.0079135 \\
\hline 2011 & 0.7054960 & 0.7951034 & 11.3031867 & 0.0208692 \\
\hline 2012 & 0.6929629 & 0.7640053 & 11.3768853 & 0.0122979 \\
\hline 2013 & 0.6476376 & 0.8219985 & 11.3900915 & 0.0084281 \\
\hline 2014 & 0.5957465 & 0.7989235 & 11.4088321 & 0.0089486 \\
\hline 2015 & 0.6109931 & 0.7685768 & 11.4039341 & 0.0071358 \\
\hline
\end{tabular}

Source: Authors
Table 2: Mean and standard deviation of the Banks

\begin{tabular}{|c|c|c|c|c|c|c|c|}
\hline \multicolumn{2}{|c|}{ LA } & \multicolumn{2}{|c|}{ DA } & \multicolumn{2}{|c|}{$\begin{array}{c}\text { Bank Size } \\
(\log \text { TA) }\end{array}$} & \multicolumn{2}{|c|}{$\mathrm{ROA}$} \\
\hline Mean & SD & Mean & SD & Mean & SD & Mean & SD \\
\hline \multicolumn{8}{|c|}{ AB Bank Limited } \\
\hline .702 & .047 & .772 & .025 & 11.321 & .109 & .007 & .002 \\
\hline \multicolumn{8}{|c|}{ Bank Asia Limited } \\
\hline .658 & .032 & .783 & .025 & 11.212 & .108 & .012 & .005 \\
\hline \multicolumn{8}{|c|}{ Dhaka Bank Limited } \\
\hline .682 & .028 & .795 & .014 & 11.152 & .086 & .013 & .006 \\
\hline \multicolumn{8}{|c|}{ Eastern Bank Limited } \\
\hline .680 & .022 & .669 & .045 & 11.191 & .080 & .017 & .005 \\
\hline \multicolumn{8}{|c|}{ Mercantile Bank Limited } \\
\hline .670 & .034 & .803 & .022 & 11.181 & .075 & .014 & .003 \\
\hline \multicolumn{8}{|c|}{ Premier Bank Limited } \\
\hline .642 & .041 & .824 & .009 & 10.982 & .100 & .008 & .001 \\
\hline \multicolumn{8}{|c|}{ Prime Bank Limited } \\
\hline .651 & .049 & .790 & .024 & 11.377 & .043 & .012 & .006 \\
\hline
\end{tabular}

Source: Authors

Table 3: Descriptive statistics of all the Banks (2011-15)

\begin{tabular}{|c|c|c|c|c|}
\hline & LA & DA & Log TA & ROA \\
\hline Mean & 0.6691 & 0.7764 & 11.2023 & 0.0119 \\
\hline Median & 0.6699 & 0.7897 & 11.1914 & 0.0115 \\
\hline SD & 0.0206 & 0.0502 & 0.1268 & 0.0034 \\
\hline Minimum & 0.6423 & 0.6688 & 10.9815 & 0.0072 \\
\hline Maximum & 0.7022 & 0.8236 & 11.3766 & 0.0171 \\
\hline
\end{tabular}

Source: Authors

From these 3 tables it is observed that the average ROA of AB Bank Limited, Bank Asia Limited, Dhaka Bank Limited, Eastern Bank Limited, Mercantile Bank Limited and Prime Bank Limited were $0.72 \%, 1.15 \%, 1.33 \%, 1.71 \%$, $1.41 \%, 0.83 \%$ and $1.15 \%$ respectively whereas the average ROA of all the banks was $1.19 \%$ during 2011-2015. The mean and median of LA were 0.6691 and 0.6699 whereas the variation in results which was determined by SD of LA was 0.02. The minimum LA was of Premier Bank Limited and the maximum LA was of AB Bank Limited. Deposit to asset ratio had a mean value of 0.7764 with an SD of 0.05 . Return on asset of the banks had the least standard deviation. The maximum DA of 0.8236 came in Premier Bank Limited and the minimum DA of 0.6688 came in Eastern Bank Limited. The bank size which was determined by the logarithm of total asset was the largest of Prime Bank Limited and was the smallest of Premier Bank Limited. Among the determinants total assets had the maximum and loan to asset ratio had the minimum deviation in results.

In table 4 the Pearson correlation analysis of LA, DA, log TA and ROA is summarized. ROA had a positive correlation of $r=0.064$ with LA and $r=0.001$ with $\log$ TA but had a negative correlation of $r=-0.624$ with DA. LA was also negatively correlated with DA. LA and log TA had a positive correlation but there was a negative correlation of $r=-0.233$ between DA and $\log$ TA. 
Table 4: Correlation analysis

\begin{tabular}{|l|c|c|c|c|c|}
\hline \multicolumn{7}{|c|}{ Correlations } \\
\hline \multirow{4}{*}{ ROA } & Pearson Correlation & 1 & .065 & -.624 & .001 \\
\cline { 2 - 6 } & Sig. (2-tailed) & & .890 & .135 & .998 \\
\cline { 2 - 6 } & N & 7 & 7 & 7 & 7 \\
\hline \multirow{4}{*}{ LA } & Pearson Correlation & .065 & 1 & -.415 & .367 \\
\cline { 2 - 6 } & Sig. (2-tailed) & .890 & & .355 & .418 \\
\cline { 2 - 6 } & N & 7 & 7 & 7 & 7 \\
\hline \multirow{4}{*}{ DA } & Pearson Correlation & -.624 & -.415 & 1 & -.233 \\
\cline { 2 - 6 } & Sig. (2-tailed) & .135 & .355 & & .616 \\
\cline { 2 - 6 } & N & 7 & 7 & 7 & 7 \\
\hline \multirow{3}{*}{ Tog } & Pearson Correlation & .001 & .367 & -.233 & 1 \\
\cline { 2 - 6 } & Sig. (2-tailed) & .998 & .418 & .616 & \\
\cline { 2 - 6 } & N & 7 & 7 & 7 & 7 \\
\hline
\end{tabular}

The result shows an insignificant relationship between profitability and liquidity and Dawood (2014) also found out that liquidity had a weak correlation with ROA. But Samad (2015) found liquidity as a significant factor for determining profitability. This study also found that the Bank size did not have much effect on the profitability and the effect was same as of Kedia (2016), Samad (2015), Dawood (2014) and Goddard et al. (2014). This table also indicates that the variables had relationships with one another, but the relationships were not significant. For this reason the null hypothesis was accepted. These relationships among the variables are insignificant and do not have a major consequence in the overall profit of the banks.

\section{CONCLUSION}

The paper examined two profitability determinants which are clearly stated as liquidity and bank size of seven commercial banks throughout 2011-2015. Mean, median, standard deviation (SD), minimum, maximum and correlation analysis statistics were used to determine the results of the study. The findings from the study indicated that the loan to asset ratio (LA) positively affected the profitability indicator ratio (ROA) of the banks. It was observed that the larger the bank size, the greater the Return on Assets of the banks. On the other hand, there was a negative impact of deposit to asset ratio (DA) on the profitability of the banks. Overall the correlation results indicated that the liquidity and the size of the banks did not significantly influence the bank's profitability. This study can be proved as a true initiative to indicate the effect of asset management and size of the bank in estimating the ROA of a bank.

\section{ACKNOWLEDGEMENT}

The authors are thankful to their parents as well as all the very honorable teachers and mentors who inspire and provide guidance in reaching one step forward toward fulfilling the aim.

\section{REFERENCES}

Alshatti, A. S. (2015). "The effect of the liquidity management on profitability in the Jordanian Commercial Banks," International Journal of Business and Management, vol. 10, no. 1, pp. 62-71.

Ayanda, A. M., Christopher, E. I. \& Mudashiru, M. A. (2013). "Determinants of banks profitability in a developing economy: Evidence from Nigerian banking Industry," Interdisciplinary Journal of Contemporary Research in Business, vol. 4, pp. 155-181.

Dawood, U. (2014). "Factors impacting profitability of commercial banks in Pakistan for the period of (2009-2012)," International Journal of Scientific and Research Publications, vol. 4, pp. 1-7.

Fisseha, F. L. (2015). "Meta analysis on the determinants of commercial bank's profitability: (A conceptual framework and modeling)," European Scientific Journal, vol. 11, no. 19, pp. 323-351.

Goddard, J., Molyneux, P. \& Wilson, J. O. S. (2014). "The profitability of European Banks: A cross-sectional and dynamic panel analysis," The Manchester School, vol. 72, no. 363-381.

Kedia, N. 2016. Determinants of profitability of Indian public sector banks. Ira-International Journal of Management \& Social Sciences. 2: 1-16.

Kumer, V. \& Sayani, H. (2015). "Application of CAMEL model on the GCC Islamic Banks: 2008-2014," Journal of Islamic Banking and Finance, vol. 3, no. 2, pp. 1-14.

Lartey, V. C., Antwi, S, \& Boadi, E. K. (2013). “The relationship between liquidity and profitability of listed banks in Ghana," International Journal of Business and Social Science, vol. 4, no. 3, pp. 48-56.

Munir, S., Ramzan, M., Iqbal, R. Q., Ahmad, M. \& Raza, A. (2012). "Financial performance assessment of banks: a case of Pakistani public sector," International Journal of Business and Social Science, vol. 3, pp. 276-283.

Ongore, V. O. \& Kusa, G. B. (2013). "Determinants of financial performance of commercial banks in Kenya," International Journal of Economics and Financial Issues, vol. 3, no. 1, pp. 237-252.

Onuonga, S. M. (2014). “The analysis of profitability of Kenya's top six commercial banks: Internal factor analysis," American International Journal of Social Science, vol. 3, pp. 94-103.

Qin, X. \& Pastory, D. (2012). “Commercial banks profitability position: The case of Tanzania," International Journal of Business of Management, vol. 7, pp. 136-144.

Saad, M. A. S. \& Zhengee, T. (2016). "The impact of organizational factors on financial performance: Building a theoretical model," International Journal of Management science and Business Administration, vol. 2, no. 7, pp. 51-56.

Samad, A. (2015). “Determinants bank profitability: Empirical evidence from Bangladesh commercial banks," International Journal of Financial Research, vol. 6, pp. 173-179.

$--0--$

Online Archive: https://abc.us.org/ojs/index.php/abr/issue/archive 